\title{
EFFECT OF FOLIAR APPLICATION OF SOME CROPS SEEDS SPROUT EXTRACTS ON FRUITING OF VALENCIA ORANGE TREES
}

\author{
Huda M. H. Ismaiel \\ Citriculture Research Department, Horticulture Research Institute, Agricultural Research Center, Giza, Egypt \\ Received on: 10/11/2019 \\ Coresponding auther email: Hudasps122@ hotmail.com
}

\begin{abstract}
Valencia orange trees has a great potentially for export to foreign markets. Appreciated any efforts directed towards enhancing yield and fruit quality. For avoiding the side effects on environmental pollution and human health by using chemical fertilizers this study was examed the use of crops seeds sprout extracts as an alternative for getting fruit quality and promoting yield on Valencia orange trees.

Crops seeds sprout extracts are of great benefits when used to spray on plants. It contains high levels of major and minor nutrients, amino acids and vitamins, which are beneficial to the crop in quantity and quality. The study relies on the use of seven crop seed sprout extracts: fenugreek (FSSE), celery (CSSE), rocket (RSSE), barley (BSSE), wheat (WSSE), garlic (GSE) and onion (OSSE) at a concentration of $0.1 \%$ in each extract.

Through the results obtained, it was found that all the extracts gives a Significant effects compared to the control on the vegetative and fruit characteristics, chemical composition of fruits, photosynthetic pigments and promoted yield and fruit quality of Valencia orange trees and found also that the crop seeds sprout extracts used in descending order were as follows: FSSE followed by CSSE, RSSE, BSSE, WSSE and finally GSE and OSSE.
\end{abstract}

KEYWORDS: Crop Seed Sprout Extract, FSSE, CSSE, RSSE, WSSE, OSSE, GSE, Valencia Orange, Photosynthetic Pigments, Fruit Setting.

\section{INTRODUCTION}

Citrus is considered the important cash crop all over the world. In Egypt, citrus ranked the first fruit crop among all cultivated fruit crops. The fruiting area and production reached 418415 fed and 4272886 tons, respectively. The fruiting area and total production of Valencia orange trees reached 102544 and 1165444 tons, respectively. (2016 statistics).

Many attempts were accomplished for improving yield and fruit quality of Valencia orange for facilitating fruit marketing and exportation it to local and to foreign markets by using natural extract. Using crops seeds germination and sprouting of different crop seed such as fenugreek, celery, rocket, barley, wheat, garlic and onion may change the content and composition of Fruits namely proteins, fats and amino acids and enhances the building and biosynthesis of essential amino acids like Glutamic acid, tryptophan, argentine, methionine and lysine, vitamin $\mathrm{B} \& \mathrm{C}$ and some macro and micro nutrients and makes them high available to the tree Table (1) and Table (2) (Cazuola et al., 2004; Cairney, 2005; Biommerson, 2007;Anwar et al., 2013 and Dhekney, 2016).

Recent studies supported the beneficial effects of using crop seed sprouts to promote growth, tree nutrition status, yield and fruit quality in detent evergreen fruit crops especially citrus, mangoes and date palms and at the same time protecting our environment from pollution (Oraby,2018 and Ali et al.,2018).

The aim of the work was examining the effect of foliar application of some crop seed sprouts (fenugreek, celery, rocket, barley, wheat, garlic and onion) on fruiting of Valencia orange trees grown under Upper Egypt conditions.

\section{MATERIALS AND METHODS}

This study was carried out during two consecutive experimental seasons 2016/2017 and 2017/2018 on uniform in vigor 35 years old Valencia orange trees (Citrus sinensis L.) onto sour orange rootstock. The selected trees are grown in a private orchard located at Malawi district Minia governorate (about $300 \mathrm{Km}$ south of Cairo). The trees planted at a spacing of $4 \times 6$ meters. The soil of the orchard is well drained clay in texture with a water table not less than two meters deep. Surface irrigation system was carried out using the procedures outlined according to (Peach and Tracey 1968) as shown in Table (4).

The selected trees were subject to the normal horticultural practices that already applied in the orchard except those dealing with using crop seed 
Scientific Journal of Agricultural Sciences 1 (2): 43-51, 2019

Table 1. Chemical analyses for FSSE and RSSE

\begin{tabular}{llll}
\hline FSSE $(\mathrm{mg} / 100 \mathrm{gFW})$ & & RSSE $(\mathrm{mg} / 100 \mathrm{gFW})$ & \\
\hline Constituent & Value & Constituent & Value \\
Asparatic acid & 2.2 & Cystine & 4.1 \\
Arginine & 2.1 & Cysteine & 3.9 \\
Alanine & 2.9 & Methionene & 3.8 \\
Isoleucin & 2.1 & Glutamic acid & 3.5 \\
Cystine & 1.9 & Thiamine & 0.16 \\
Cysteine & 1.8 & Riboflavin & 0.15 \\
Glutamic acid & 2.0 & Vitamin E & 0.94 \\
Methionene & 6.0 & Vitamin A & 4.4 \\
Lysine & 5.1 & Vitamin C & 101 \\
Vitamin A & 1.0 & K & 496 \\
Vitamin B1 & 0.32 & P & 1410 \\
Vitamin B2 & 0.30 & Mg & 460 \\
Vitamin B6 & 1.00 & Fe & 267 \\
Vitamin C & 2.00 & Mn & 16 \\
Ca & 220 & Zn & 255 \\
P & 341 & & \\
K & 469 & & \\
Mg & 371 & & \\
Fe & 242 & & \\
Phytic acid & 0.9 & & \\
Niacin & 1.4 & &
\end{tabular}

Table 2. Chemical analyses for BSSE and WSSE

\begin{tabular}{llll}
\hline BSSE$(\mathrm{mg} / 100 \mathrm{gFW})$ & & WSSE$(\mathrm{mg} / 100 \mathrm{gFW})$ & \\
\hline Constituent & Value & Constituent & Value \\
Asparatic acid & 2.1 & Arginine & 4.0 \\
Arginine & 3.5 & Alanine & 3.1 \\
Alanine & 2.9 & Isoleucine & 4.1 \\
Isoleucin & 2.0 & Glutamic acid & 5.2 \\
Glutamic acid & 4.7 & Thiamine & 3.1 \\
Thiamine & 2.5 & Riboflavin & 3.00 \\
Lysine & 1.9 & Asparatic acid & 3.3 \\
Vitamin E & 0.61 & Pyridoxine & 2.5 \\
Riboflavin & 3.00 & Vitamin E & 0.59 \\
Pyridoxine & 1.9 & $\mathrm{~K}$ & 644 \\
Ca & 280 & $\mathrm{P}$ & 600 \\
$\mathrm{P}$ & 510 & $\mathrm{Mg}$ & 319 \\
$\mathrm{~K}$ & 600 & $\mathrm{Fe}$ & 511 \\
$\mathrm{Mg}$ & 281 & $\mathrm{Ca}$ & 292 \\
$\mathrm{Fe}$ & $\mathrm{Zn}$ & 218 \\
$\mathrm{Zn}$ & 181 & & \\
\hline
\end{tabular}

sprout extracts. This investigation consisted of eight treatments arranged as follows:

1-control

2 -spraying onion seed sprout at $0.1 \%$

3 -spraying garlic sprout at $0.1 \%$

4-spraying barley seed sprout at $0.1 \%$

5 -spraying wheat seed sprout at $0.1 \%$

6 -spraying rocket seed sprout at $0.1 \%$

7 -spraying celery seed sprout at $0.1 \%$
8- spraying fenugreek seed sprout at $0.1 \%$

Each treatment was replicated three times, one tree per each. The seven seeds of crops extracts (fenugreek, celery, rocket, barley, wheat, garlic and onion) were sprayed three times at growth start (2nd of Mar) just after fruit setting (Last week of Apr) and one month later (last week of May) triton B as a wetting agent was added to all extract at $0.05 \%$ and spraying was done till run off . 
Huda M. H. Ismaiel., 2019

Table 3. Chemical analyses for GSE(oil) andOSSE

\begin{tabular}{llll}
\hline OSSE $(\mathrm{mg} / 100 \mathrm{gFW})$ & & G Oil & \\
\hline Constituent & Value & Constituent & Value \\
Protein \% & 3.2 & Glutamic acid & $2.3-2.7$ \\
Fat \% & 0.1 & Pantotheonic acid $(\mathrm{mg})$ & 0.14 \\
Carbohydrates \% & 13.8 & Cysteine & $1.0-1.2$ \\
Fibre \% & 0.4 & Cystine & $1.4-1.7$ \\
ash \% & 81.5 & Methionene & $1.9-2.1$ \\
$\mathrm{Ca}(\mathrm{gm})$ & 220 & Arginine & $2.2-2.5$ \\
$\mathrm{Fe}(\mathrm{gm})$ & 1 & Vitamin D $(\mathrm{mg})$ & 0.3 \\
$\mathrm{Mg}(\mathrm{gm})$ & 11 & Riboflavin $(\mathrm{mg})$ & 0.05 \\
$\mathrm{P}(\mathrm{gm})$ & 79 & Nicotinic acid $(\mathrm{mg})$ & 0.2 \\
$\mathrm{~K}(\mathrm{gm})$ & 212 & Vitamin C $(\mathrm{mg})$ & 10.0 \\
$\mathrm{Zn}(\mathrm{gm})$ & 1 & Folic acid $(\mathrm{mg})$ & 16.0 \\
& & Biotin $(\mathrm{mg})$ & 0.9 \\
& & $\mathrm{Zn}$ & $1.5-2.8$ \\
& & $\mathrm{Mn}$ & $0.5-1.0$ \\
& & $\mathrm{~S}$ & $50-51$ \\
& & $\mathrm{Ca}$ & $190-540$ \\
& & $\mathrm{P}$ & $200-430$ \\
& & $\mathrm{~K}$ & $80-110$ \\
& & $\mathrm{Na}$ & $31-50$ \\
& & $\mathrm{Mg}$ & $81-150$ \\
& & $\mathrm{Al}$ & $0.5-1.0$ \\
& & $\mathrm{Ba}$ & $0.1-1.0$ \\
& & $\mathrm{Fe}$ & $1.8-2.6$ \\
& $\mathrm{Sr}$ & $0.08-7.0$ \\
& & $\mathrm{~B}$ & $0.6-1.0$ \\
& & $\mathrm{Cu}$ & $0.05-0.64$ \\
\hline
\end{tabular}

Source: Peter (1999).

Source: Fenwich and Hanley, 1990.

Table 4. Analysis of the soil at trial location

\begin{tabular}{lc}
\hline Constituents & Values \\
\hline Sand\% & 4.0 \\
Silt\% & 16.0 \\
Clay\% & 80 \\
Texture & clay \\
O.M.\% & 2.25 \\
PH(1:2.5exract) & 8.11 \\
E.C (1:2.5exract)(memos/cm/25c) & 1.14 \\
CaCo3\% & 1.22 \\
Available\% & 0.09 \\
Available P (Olsen method.ppm) & 4.50 \\
Available K (ammonium acetate, pap) & 45.0 \\
\hline
\end{tabular}

\subsection{Preparation of the extracts:}

Extracts of the seven crop seed sprout were prepared by germinating of the seeds when the plant height reached Ten $\mathrm{cm}$, they were harvested and put in the refrigerator at $10^{\circ} \mathrm{C}$ till use, As the time of application they were blended in electric blinder .
Complete randomized block design (CRBD) was adopted which the experiment included eight Treatments and each treatment was replicated three times, one tree per each during both seasons and statistical analysis was done and treatments means were compared using new L.S.D. at 5\% (Snedecor and Cochran, 1980). 
The following measurements were recorded:

1- Vegetative growth Characteristics namely shoot length, number of leaves / shoot, shoot thickness and leaf area (cm2) by (Ahmed and Morsy, 1999)

2- Leaf pigments namely chlorophylls $\mathrm{a} \& \mathrm{~b}$,total chlorophylls and total carotenoids (as mg/lg F.W) (Von-Wettstein,1957)

3- Total carbohydrates (A.O.A.C.,2006)

4- Leaf chemical components namely N. P .K .S and $\mathrm{Ca}($ as $\%$ ) and $\mathrm{Zn}, \mathrm{Fe}$ and $\mathrm{Mn}$ (as ppm) (Cottenie et al.,1982 andSummer,1985).

5- Percentages of initial fruit setting and fruit retention.

6- Number of fruits per tree and yield /tree $(\mathrm{Kg})$ was calculated (1st week of April).

7- Physical and chemical characteristics of the fruit namely fruit weight $(\mathrm{g})$ and dimension (height and diameter as $\mathrm{cm}$ ), percentages of juice and fruit peel weight, fruit peel thickness (as $\mathrm{cm}$ ), T.S.S\%, total acidity\% (as g. citric acid/100 ml juice) T.S.S./acid, total and reducing sugars\% (lane and Eynon, 1965) vitamin C content (mg/100 ml juice)(A.O.A.C,2006).

\section{RESULTS}

\subsection{Vegetative criteria:}

Data in Table (5) clearly shows that spraying trees three times with any seed sprout namely Onion, garlic, barley, wheat, rocket, celery and fenugreek each at $0.1 \%$. Significantly shows the four growth aspects of Valencia orange trees namely shoot length, number of leaves, shoot thickness and leaf area in the spring growth cycle relative to the control treatments. Significant differences of these growth traits were observed as the results of the seven crop seed sprouts applications. The maximum values were presented in the tree sprayed with Onion, barley, wheat, rocket, garlic, celery and fenugreek seed sprout extracts. Onion occupied the last position in this respect .The maximum values were recorded on the tree treated with fenugreek seed sprout .The untreated tree produced the minimum values. This result were true during both season.

Table 5. Effect of spraying some crops seed sprout on some Vegetative criteria of Valencia orange trees during 2016/2017 and 2017/2018 seasons.

\begin{tabular}{lllllllll}
\hline \multirow{2}{*}{ Treatments } & \multicolumn{2}{l}{ Shoot length $(\mathbf{c m})$} & \multicolumn{2}{l}{ No of leaves/shoot } & \multicolumn{2}{l}{ Shoot thickness $(\mathbf{m m})$} & \multicolumn{2}{c}{ Leaf area $\left(\mathbf{c m}^{2}\right)$} \\
\cline { 2 - 8 } & $\mathbf{2 0 1 6 / 2 0 1 7}$ & $\mathbf{2 0 1 7 / 2 0 1 8}$ & $\mathbf{2 0 1 6 / 2 0 1 7}$ & $\mathbf{2 0 1 7 / 2 0 1 8}$ & $\mathbf{2 0 1 6 / 2 0 1 7}$ & $\mathbf{2 0 1 7 / 2 0 1 8}$ & $\mathbf{2 0 1 6 / 2 0 1 7}$ & $\mathbf{2 0 1 7 / 2 0 1 8}$ \\
\hline CT & 3.9 & 4.0 & 3.0 & 3.0 & 1.40 & 1.37 & 20.1 & 19.9 \\
OSSE & 4.4 & 4.4 & 4.0 & 4.0 & 1.52 & 1.53 & 20.6 & 20.4 \\
BSSE & 4.9 & 4.7 & 4.0 & 4.0 & 1.66 & 1.68 & 21.2 & 20.8 \\
WSSE & 5.4 & 5.1 & 5.0 & 4.0 & 1.80 & 1.84 & 21.9 & 21.4 \\
RSSE & 5.7 & 5.5 & 5.0 & 4.0 & 1.92 & 2.00 & 23.0 & 21.9 \\
GSE & 6.3 & 5.9 & 5.0 & 5.0 & 2.06 & 2.15 & 23.5 & 23.0 \\
CSSE & 6.6 & 6.3 & 6.0 & 5.0 & 2.20 & 2.31 & 24.0 & 23.5 \\
FSSE & 7.0 & 6.7 & 6.0 & 5.0 & 2.33 & 2.45 & 24.6 & 24.1 \\
New LSD 5 \% & 0.3 & 0.3 & 1.0 & 1.0 & 0.11 & 0.14 & 0.5 & 0.4 \\
\hline
\end{tabular}

\subsection{Leaf chemical components:}

It is evident from the data in Tables $(6,7 \& 8)$ that subjecting the tress to the seven crop seed sprouted extracts namely Onion, garlic ,barley, wheat rocket ,celery and fenugreek each at $0.1 \%$ were significantly Table 6. Effect of spraying some crops seed sprout on some photosynthetic pigments in the leaves of Valencia orange trees during 2016/2017 and 2017/2018 seasons

\begin{tabular}{|c|c|c|c|c|c|c|c|c|c|c|}
\hline \multirow[t]{2}{*}{$\begin{array}{l}\text { Treatme } \\
\text { nts }\end{array}$} & \multicolumn{2}{|c|}{$\begin{array}{l}\text { Chlorophyll a } \\
\text { (mg/g F.W.) }\end{array}$} & \multicolumn{2}{|c|}{$\begin{array}{c}\text { Chlorophyll b } \\
\text { (mg/g F.W.) }\end{array}$} & \multicolumn{2}{|c|}{$\begin{array}{l}\text { Total Chlorophyll } \\
\text { (mg/g F.W.) }\end{array}$} & \multicolumn{2}{|c|}{$\begin{array}{c}\text { Total carotenoids } \\
\left(\mathrm{mg} / \mathrm{g} \mathrm{F} . \mathrm{W}^{\prime}\right)\end{array}$} & \multicolumn{2}{|c|}{$\begin{array}{l}\text { Total } \\
\text { carbohydrates } \%\end{array}$} \\
\hline & 2016/2017 & $2017 / 2018$ & $2016 / 2017$ & $2017 / 2018$ & 2016/2017 & $2017 / 2018$ & 2016/2017 & $2017 / 2018$ & $2016 / 2017$ & $2017 / 2018$ \\
\hline CT & 3.1 & 2.9 & 1.0 & 0.9 & 4.1 & 3.8 & 1.0 & 0.9 & 14.0 & 13.9 \\
\hline OSSE & 3.6 & 3.5 & 1.3 & 1.2 & 4.9 & 4.7 & 1.3 & 1.2 & 14.5 & 14.6 \\
\hline BSSE & 4.1 & 4.0 & 1.5 & 1.5 & 4.6 & 5.5 & 1.6 & 1.5 & 15.0 & 15.1 \\
\hline WSSE & 4.7 & 4.6 & 1.7 & 1.8 & 6.4 & 6.4 & 1.9 & 1.7 & 15.6 & 15.7 \\
\hline RSSE & 5.3 & 5.2 & 2.0 & 2.1 & 7.3 & 7.3 & 2.1 & 2.0 & 16.2 & 16.3 \\
\hline GSE & 6.0 & 5.6 & 2.2 & 2.4 & 8.2 & 8.0 & 2.3 & 2.2 & 16.8 & 17.0 \\
\hline CSSE & 6.5 & 6.0 & 2.4 & 2.7 & 8.9 & 8.7 & 2.6 & 2.2 & 17.3 & 17.6 \\
\hline FSSE & 7.0 & 6.5 & 2.7 & 3.0 & 9.7 & 9.5 & 2.8 & 2.5 & 17.8 & 18.3 \\
\hline $\begin{array}{l}\text { New LSD } \\
5 \%\end{array}$ & 0.4 & 0.5 & 0.2 & 0.3 & 0.4 & 0.5 & 0.2 & 0.2 & 0.5 & 0.6 \\
\hline
\end{tabular}


Huda M. H. Ismaiel., 2019

Table 7. Effect of spraying some crops seed sprout on percentage of $\mathrm{N}, \mathrm{P}, \mathrm{K}$ and $\mathrm{Ca}$ on the leaves of Valencia orange trees during 2016/2017 and 2017/2018 seasons.

\begin{tabular}{|c|c|c|c|c|c|c|c|c|}
\hline \multirow[t]{2}{*}{ Treatments } & \multicolumn{2}{|l|}{ Leaf N\% } & \multicolumn{2}{|l|}{ Leaf $P$ \% } & \multicolumn{2}{|l|}{ Leaf K\% } & \multicolumn{2}{|l|}{ Leaf Ca\% } \\
\hline & 2016/2017 & $2017 / 2018$ & 2016/2017 & $2017 / 2018$ & 2016/2017 & $2017 / 2018$ & $2016 / 2017$ & $2017 / 2018$ \\
\hline CT & 1.56 & 1.59 & 0.211 & 0.201 & 1.11 & 1.04 & 2.41 & 2.39 \\
\hline OSSE & 1.61 & 1.64 & 0.222 & 0.212 & 1.16 & 1.14 & 2.51 & 2.50 \\
\hline BSSE & 1.66 & 1.68 & 0.233 & 0.224 & 1.21 & 1.19 & 2.60 & 2.60 \\
\hline WSSE & 1.71 & 1.73 & 0.250 & 0.236 & 1.26 & 1.23 & 2.70 & 2.69 \\
\hline RSSE & 1.77 & 1.77 & 0.263 & 0.250 & 1.31 & 1.27 & 2.80 & 2.79 \\
\hline GSE & 1.83 & 1.82 & 0.275 & 0.269 & 1.36 & 1.33 & 2.90 & 2.90 \\
\hline CSSE & 1.88 & 1.86 & 0.287 & 0.281 & 1.41 & 1.38 & 3.01 & 3.01 \\
\hline FSSE & 1.94 & 1.90 & 0.305 & 0.294 & 1.46 & 1.43 & 3.11 & 3.12 \\
\hline New LSD 5 & 0.05 & 0.04 & 0.010 & 0.009 & 0.04 & 0.04 & 0.07 & 0.08 \\
\hline
\end{tabular}

Table 8. Effect of spraying some crops seed sprout on percentage of $\mathrm{Zn}, \mathrm{Fe}, \mathrm{Mn}$ and $\mathrm{S}$ on the leaves of Valencia orange trees during 2016/2017 and 2017/2018 seasons.

\begin{tabular}{|c|c|c|c|c|c|c|c|c|}
\hline \multirow[t]{2}{*}{ Treatments } & \multicolumn{2}{|c|}{ Leaf Zn (ppm) } & \multicolumn{2}{|c|}{ Leaf Fe (ppm) } & \multicolumn{2}{|c|}{ Leaf Mn (ppm) } & \multicolumn{2}{|l|}{ Leaf S\% } \\
\hline & 2016/2017 & $2017 / 2018$ & $2016 / 2017$ & $2017 / 2018$ & $2016 / 2017$ & $2017 / 2018$ & 2016/2017 & $2017 / 2018$ \\
\hline CT & 49.9 & 50.0 & 54.0 & 55.0 & 60.4 & 59.1 & 0.69 & 0.70 \\
\hline OSSE & 54.0 & 54.0 & 57.5 & 59.0 & 64.4 & 63.0 & 0.73 & 0.74 \\
\hline BSSE & 56.9 & 57.0 & 60.9 & 62.5 & 68.5 & 66.0 & 0.79 & 0.79 \\
\hline WSSE & 59.9 & 60.0 & 63.9 & 66.0 & 71.9 & 70.0 & 0.84 & 0.86 \\
\hline RSSE & 63.0 & 62.9 & 64.9 & 69.0 & 76.0 & 73.0 & 0.88 & 0.90 \\
\hline GSE & 67.0 & 66.9 & 70.9 & 72.0 & 79.0 & 77.0 & 0.92 & 0.93 \\
\hline CSSE & 69.9 & 70.0 & 73.5 & 75.0 & 82.9 & 80.0 & 0.96 & 0.98 \\
\hline FSSE & 74.0 & 74.0 & 78.9 & 78.0 & 85.0 & 82.9 & 1.01 & 1.01 \\
\hline $\begin{array}{l}\text { New LSD } 5 \\
\%\end{array}$ & 2.7 & 2.9 & 2.4 & 2.5 & 2.7 & 2.6 & 0.03 & 0.03 \\
\hline
\end{tabular}

follows : Onion, barley, wheat, rocket, garlic, celery and fenugreek, Onion significant occupied the last position in this respect significant on the other hand the highest values were observed on trees that sprayed with fenugreek seed sprout that was responsible for maximizing these leaf chemical component these results were true during 2016/2017 and 2017/2018 seasons.

\subsection{Perecent of initial fruit setting and yield per tree}

Table (9) shows that the parentages of initial fruit setting and fruit retention as well as yield expressed in weight and number of fruits /tree were significantly improved relating to the use of the seven crop seed sprouts at $0.1 \%$ relative to the control. The promotion on these parameters was significantly associated with spraying crop seed sprouts Onion, barley, wheat, rocket, garlic, celery and fenugreek in ascending order significant differences of fruit setting and yield were observed among the seven crop seed sprouts. The best crop seed sprouts was fenugreek followed by celery and Onion, ranked the last position in this respect. The lowest values of yield expressed in weight (56 \&58 $\mathrm{Kg}$ ) during both seasons were recorded on untreated tree while the highest values $(80.1 \& 81.0 \mathrm{Kg})$ were recorded on the tree treated with crop seed sprouts namely fenugreek during both season respectively. The parentage it accruement does to application of fenugreek over the control reached and respectively. These results were true during both seasons.

\subsection{Fruit Physical and chemical characterizations}

Over mentioned data in tables $(10,11 \& 12)$ showed that supplying Valencia orange trees three times with the seven crop seed sprouts each at $0.1 \%$ significantly enhanced fruit quality in term of fruit height, diameter, juice, T.S.S., T.S.S./acidity, was very effective in enhancing fruit quality These treatments were increased fruit height and diameter , juice \%, T.S. S.\%, total and reducing sugars \%,T. S. S /acid and vitamin $\mathrm{C}$ in addition to decrease fruit peel weight and thickness and total acidity $\%$ relative to the control. The promotion on both physical and chemical characterizing of the fruit was related in ascending order to the application with Onion, barley, wheat, rocket, garlic, celery and fenugreek. Significant differences in this respect was observed among the seven seed sprouts the best result recorded on fenugreek seed sprout, the last was onion seed sprout and unfavorable effect in fruit quality was attributed 
Scientific Journal of Agricultural Sciences 1 (2): 43-51, 2019

Table 9. Effect of spraying some crops seed sprout on Initial fruit setting \%, fruit retention \%, Number of fruit / tree and yield of Valencia orange trees during 2016/2017 and 2017/2018 seasons

\begin{tabular}{|c|c|c|c|c|c|c|c|c|}
\hline \multirow[t]{2}{*}{ Treatments } & \multicolumn{2}{|c|}{ Initial fruit setting \% } & \multicolumn{2}{|c|}{ Fruit retention \% } & \multicolumn{2}{|c|}{ Number of fruit / tree } & \multicolumn{2}{|c|}{ Yield / tree ( Kg.) } \\
\hline & $2016 / 2017$ & $2017 / 2018$ & $2016 / 2017$ & $2017 / 2018$ & $2016 / 2017$ & $2017 / 2018$ & $2016 / 2017$ & $2017 / 2018$ \\
\hline CT & 10.0 & 9.6 & 0.74 & 0.71 & 350 & 360 & 56.0 & 58.0 \\
\hline OSSE & 10.5 & 10.6 & 0.80 & 0.80 & 370 & 369 & 59.9 & 60.5 \\
\hline BSSE & 11.0 & 11.1 & 0.85 & 0.86 & 380 & 381 & 62.7 & 63.6 \\
\hline WSSE & 11.6 & 11.8 & 0.91 & 0.92 & 390 & 392 & 65.5 & 66.6 \\
\hline RSSE & 12.3 & 12.5 & 0.96 & 1.01 & 405 & 405 & 68.9 & 69.7 \\
\hline GSE & 13.0 & 13.3 & 1.03 & 1.10 & 420 & 421 & 72.7 & 73.9 \\
\hline CSSE & 13.5 & 14.0 & 1.10 & 1.16 & 431 & 435 & 76.1 & 77.2 \\
\hline FSSE & 14.3 & 14.7 & 1.16 & 1.22 & 445 & 450 & 80.1 & 81.0 \\
\hline $\begin{array}{l}\text { New LSD } 5 \\
\%\end{array}$ & 0.5 & 0.6 & 0.05 & 0.06 & 10.0 & 9.0 & 0.7 & 0.8 \\
\hline
\end{tabular}

Table 10. Effect of spraying some crops seed sprout on some physical characteristics of Valencia orange Fruits during 2016/2017 and 2017/2018 seasons.

\begin{tabular}{lllllllll}
\hline Treatments & \multicolumn{2}{l}{ Fruit weight (g.) } & \multicolumn{2}{l}{ Fruit height $(\mathbf{c m})$} & \multicolumn{2}{l}{ Fruit diameters $(\mathbf{c m})$} & Juice \% \\
\cline { 2 - 8 } & $\mathbf{2 0 1 6 / 2 0 1 7}$ & $\mathbf{2 0 1 7 / 2 0 1 8}$ & $\mathbf{2 0 1 6 / 2 0 1 7}$ & $\mathbf{2 0 1 7 / 2 0 1 8}$ & $\mathbf{2 0 1 6 / 2 0 1 7}$ & $\mathbf{2 0 1 7 / 2 0 1 8}$ & $\mathbf{2 0 1 6 / 2 0 1 7}$ & $\mathbf{2 0 1 7 / 2 0 1 8}$ \\
\hline CT & 160.0 & 161.0 & 6.8 & 7.0 & 6.3 & 6.2 & 40.0 & 40.5 \\
OSSE & 162.0 & 164.0 & 7.1 & 7.2 & 6.6 & 6.4 & 41.0 & 41.5 \\
BSSE & 165.0 & 167.0 & 7.3 & 7.5 & 7.0 & 6.6 & 42.0 & 43.0 \\
WSSE & 168.0 & 170.0 & 7.6 & 7.7 & 7.3 & 7.0 & 43.0 & 44.0 \\
RSSE & 170.0 & 172.0 & 7.8 & 8.0 & 7.6 & 7.3 & 43.9 & 45.0 \\
GSE & 173.0 & 176.0 & 8.0 & 8.2 & 7.8 & 7.6 & 45.0 & 46.0 \\
CSSE & 175.0 & 179.0 & 8.2 & 8.4 & 8.0 & 7.9 & 46.0 & 47.0 \\
FSSE & 178.0 & 182.0 & 8.5 & 8.6 & 8.2 & 8.3 & 46.9 & 48.1 \\
New LSD 5 & 2.0 & 2.2 & 0.2 & 0.2 & 0.2 & 0.2 & 0.8 & 1.0 \\
\% & & & & & & & & \\
\hline
\end{tabular}

Table 11. Effect of spraying some crops seed sprout on some physical characteristics of Valencia orange Fruits during 2016/2017 and 2017/2018 seasons.

\begin{tabular}{lllllllll}
\hline Treatments & \multicolumn{2}{l}{ Fruit peel weight \% } & \multicolumn{2}{l}{ Fruit peel thickness } & \multicolumn{2}{l}{ T.S.S\% } & \multicolumn{2}{c}{ Total acidity \% } \\
\cline { 2 - 9 } & $\mathbf{2 0 1 6 / 2 0 1 7}$ & $\mathbf{2 0 1 7 / 2 0 1 8}$ & $\mathbf{2 0 1 6 / 2 0 1 7}$ & $\mathbf{2 0 1 7 / 2 0 1 8}$ & $\mathbf{2 0 1 6 / 2 0 1 7}$ & $\mathbf{2 0 1 7 / 2 0 1 8}$ & $\mathbf{2 0 1 6 / 2 0 1 7}$ & $\mathbf{2 0 1 7 / 2 0 1 8}$ \\
\hline CT & 24.0 & 25.0 & 0.42 & 0.41 & 11.0 & 10.9 & 1.340 & 1.344 \\
OSSE & 23.0 & 24.1 & 0.39 & 0.39 & 11.3 & 11.5 & 1.314 & 1.327 \\
BSSE & 22.1 & 23.6 & 0.36 & 0.37 & 11.7 & 11.9 & 1.291 & 1.300 \\
WSSE & 21.4 & 23.0 & 0.33 & 0.34 & 12.1 & 12.3 & 1.269 & 1.271 \\
RSSE & 20.6 & 22.0 & 0.30 & 0.32 & 12.4 & 12.6 & 1.240 & 1.246 \\
GSE & 20.0 & 20.4 & 0.28 & 0.29 & 12.8 & 13.0 & 1.1220 & 1.226 \\
CSSE & 19.2 & 19.8 & 0.26 & 0.27 & 13.1 & 13.3 & 1.201 & 1.200 \\
FSSE & 18.5 & 19.0 & 0.24 & 0.24 & 13.5 & 13.6 & 1.180 & 1.171 \\
New LSD & 0.6 & 0.5 & 0.2 & 0.2 & 0.3 & 0.3 & 0.014 & 0.012 \\
\% & 0.6 & & & & & & & \\
\hline
\end{tabular}


Huda M. H. Ismaiel., 2019

Table 12. Effect of spraying some crops seed sprout on some physical characteristics of Valencia orange Fruits during 2016/2017 and 2017/2018 seasons.

\begin{tabular}{|c|c|c|c|c|c|c|c|c|}
\hline \multirow[t]{2}{*}{ Treatments } & \multicolumn{2}{|l|}{ T.S.S/ acid } & \multicolumn{2}{|c|}{ Total sugars \% } & \multicolumn{2}{|c|}{ Reducing sugars \% } & \multicolumn{2}{|c|}{$\begin{array}{l}\text { Vitamin } \mathrm{C}(\mathrm{mg} / 100 \mathrm{ml}) \\
\text { juice }\end{array}$} \\
\hline & 2016/2017 & $2017 / 2018$ & 2016/2017 & $2017 / 2018$ & 2016/2017 & $2017 / 2018$ & $2016 / 2017$ & $2017 / 2018$ \\
\hline CT & 8.2 & 8.1 & 7.4 & 7.6 & 2.9 & 3.0 & 44.1 & 45.3 \\
\hline OSSE & 8.6 & 8.7 & 7.7 & 7.9 & 3.3 & 3.3 & 46.0 & 46.3 \\
\hline BSSE & 9.1 & 9.2 & 8.0 & 8.2 & 3.6 & 3.6 & 47.9 & 48.2 \\
\hline WSSE & 9.5 & 9.7 & 8.3 & 8.5 & 3.9 & 4.0 & 49.9 & 50.3 \\
\hline RSSE & 10.0 & 10.1 & 8.6 & 8.8 & 4.2 & 4.3 & 52.0 & 52.5 \\
\hline GSE & 10.5 & 10.6 & 9.0 & 9.1 & 4.4 & 4.6 & 54.0 & 55.0 \\
\hline CSSE & 11.0 & 11.1 & 9.4 & 9.4 & 4.7 & 5.0 & 55.7 & 57.8 \\
\hline FSSE & 11.4 & 11.6 & 9.8 & 9.9 & 5.0 & 5.3 & 58.0 & 59.9 \\
\hline $\begin{array}{l}\text { New LSD } 5 \\
\%\end{array}$ & 0.3 & 0.3 & 0.2 & 0.2 & 0.2 & 0.2 & 1.0 & 0.9 \\
\hline
\end{tabular}

Table 13. Expected net profit for the suggested treatments when applied in one fed. Contains 122 Valencia orange trees during 2016/2017 and 2017/2018 seasons.

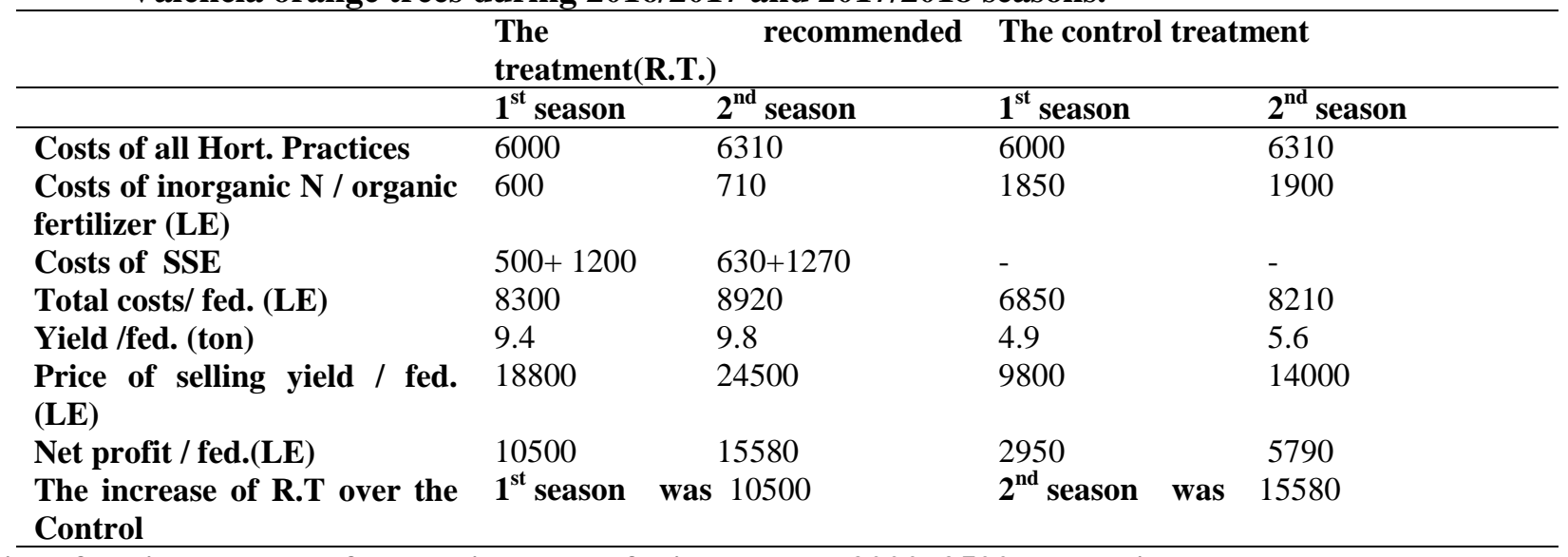

Price of selling one ton of Valencia orange fruits reached 2000, 2500 LE during both seasons.

to the untreated trees .Similar trend was observed during both seasons. Over mentioned data in Table (13) showed that by applying the recommended treatment net profit will get in the first and second seasons respectively $10500,15580 \mathrm{LE}$ Compared to the control treatment will gets 2950, 5790 LE. During both seasons.

\section{Discussion}

Crop the higher content of all seed sprouts from nutrients amino acids, vitamins, antioxidant and plant pigments surely reflected an enhancing growth tree, nutritional status, yield and fruit quality (Camacho et al. 1992, cazuola, 2004 and Cairney, 2005).

In addition, germination of seeds lead to enhance the availability of most organic and mineral nutrients (Biommerson,2007, Anwar et al.,2013 and Dhekney,2016) the promotion on growth and tree nutrition of status surely reflected on enhancing yield and fruit quality. These results are in harmony with those obtained by (Al-wasfy et al. (2013), Mohamed (2014), El-khawaga and Mansour(2014), Refaai (2014a) and (2014b); Ahmed (2015); shoug (2015),Abdel -Rahman(2015) Abdelaziz et al. (2017), Oraby (2018) and Ali et al.(2018).

\section{Conclusion}

Through the results obtained, it was found that all the extracts gives a significant effect compared to the control and spraying trees sprout three times at growth started, just after fruit setting and one month later of fenugreek or celery each at $0.1 \%$ was responsible for improving or promoting yield and fruit quality of Valencia orange trees under Mallawy district,Minia Governorate and it's similar conditions. 


\section{REFERENCES}

Abdel aziz FH, Hussein YA and Abd El-latif WMR (2017).

Productive capacity of Valencia orange tree as effected with spraying some crop seed sprout extracts. New York. J. Sci.120-128.

Abdel-Rahman MMA (2015). Yield and fruit quality of Washington navel oranges as influenced by foliar application of fenugreek and rocket seed sprouts World Rural Observation 7 (2):99-104.

Ahmed AMA (2015). Effect of spraying fenugreek seed sprout extract and some nutrients on fruiting of keitte mango trees grown under Aswan region conditions . Alex .J. Agric. Res. 60(2):33-40.

Ahmed FF and Morsy MH (1999). A new method for measuring leaf area in different fruit species . Mini J. OF Agric .Res . 8 Develop .,Vo1. (19) pp.97-105.

Ali AH, Refaai MM and Abd El-Baset - Heba R (2018). Improving productivity of Ewaise mango trees by using seed sprout extract of wheat beside carboxylic acid enriched with some macro and micro nutrients Researcher 10 (12).30-38.

AL-Wasfy MM, Ahmed FF and EL- Masry AM (2013). Behavior of Washington Navel orange trees to foliar application of some plant extracts. Hort science journal of Suez canal Univ. Vo1 . 1:281 - 285.

Anwar SA, Hifnawy AK, Kandel AM and Abdallah MF (2013). Nutritional and health related constitutions of fenugreek, sunflower and mustared sprouts as a functional food .Annals Agric. Sci 50(1) 175-189.

Association of Official Agricultural Chemists (2006). Official Method of Analysis (A.P.A.C.) $15^{\text {th }}$ Ed., published by A.O.A.C. Washington, D.C.(U.S.A.)pp. 490-510.

Biommerson A (2007). Cruciferous sprout complex. Monograph, 227 Bellevue way NE, pp 83.

Cairney E (2005). The sprouters handbook Argyll publishing Glendranel, Argyll PA 223 A 223 A E Scotland pp. 41-45.

Camacho, LC, Slerra C, Compos R, Guzmane and Marches (1992). Nutritional changes caused by the germination of legumes commonly eaten in China .arch Latina $\mathrm{c} \mathrm{h}$. nutria. 42:283-290.

Cazuola I, Marsili V and Gainfrancshi GLK (2004). Synthesis of antioxidants in wheat sprouts. J. Agric. Chen. 52:5201-5206.
Cottenie A, Verloo M, Velghe $M$ and Camerlynck R (1982). Chemical analysis of plant and soil. Ghent, Belgium, laboratory of Analytical and AgroChemistry. State Univ. Pp. 200-210.

Dhekney SA (2016). Encyclopedia of food and health . Academic press, Oxfor . pp. 261-265.

El-khawaga AS and Mansour AGM (2014). Promoting productivity of Washington navel orange trees by using some crop seed sprout extracts, silicon and glutathione. Middle East Journal of Applied Sciences , 4(3):779-785.

Lane JH and Eynon L (1965). Determination of reducing sugars by means of Fehlings solution with methylene blue as indicator A.O.A.C.Ms A490-510.

Mohamed AY (2014). Effect of spraying fenugreek and sprout and some nutrients on fruiting of keitte mango trees grown under Aswan region conditions. World Rural Observations 6 (14):103-108.

Oraby AF (2018). Response of Ewaise mango trees grown under upper Egypt conditions to foliar application of some nutrients, plant extracts, Silicon and Selenium. Ph.D. Thesis Fac. of Agric. Minia Univ. Egypt.

Peach K and Tracey, 1MV (1968). Modern methods of plants analysis, Vol. ii, p. 36-38. Inter Sci . New York.

Refaai MM (2014a). Impact of spaying extracts of fenugreek and rocket seed sprouts on fruiting of keitte mango trees World Rural Observations, 6(4), 75-80.

Refaai MM (2014b). Response of Zaghloul date palms grown under minia region conditions to spraying wheat seed sprout extract and Nano- boron . Stem Cell 5 (4);22-25.

Shoug MAF (2015). Effect of spraying some plant extracts on fruiting and storage of Balady Mandarin fruits on the trees. M. Sc,. Thesis Fac. Of Agric, AlAzhar Univ. Assuit branch, Egypt.

Snedecor GAV and Cochran GW (1980). Statistical methods $.7^{\text {th }} \mathrm{ED}$. Iowa state Univ. press. Ames:Iowa, U. S. A. 507.

Summer ME (1985). Diagnosis and recommendation integrated system (DRIS) as a guide to orchard fertilization .Hort. Abst., 55(8):7502.

Von-wettstein DY (1957). Chlroophyll -lethalc under submikroshopische formilkechrel der plastiden celi, prp. Trop. Res. Amer. Soc. Hort. Sci. 20 pp. 427433. 
Huda M. H. Ismaiel., 2019

$$
\text { الملخص العربي }
$$

\section{"تأثير الرش الورقي لنبت بذور بعض المحاصيل على الإثمار في أثجار البرتقال الفالنشيا"}

\section{هاي محمد حسن اسماعيل}

$$
\text { * قسم بحوث الموالح - معهد بحوث البساتين - مركز البحوث الزئر اعية بالجيزة }
$$

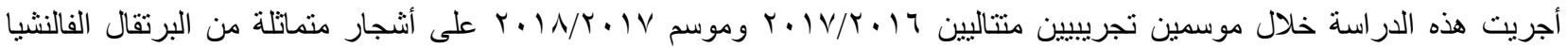

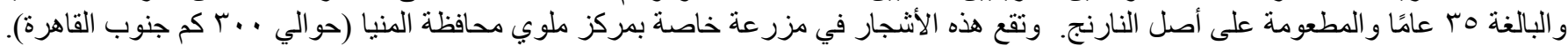

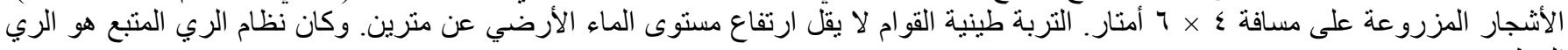

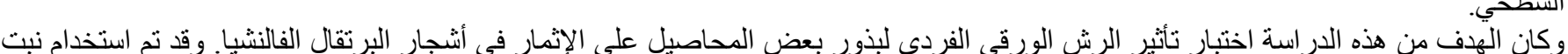

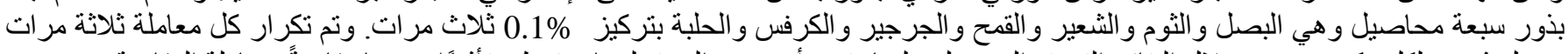

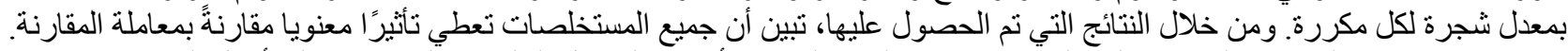

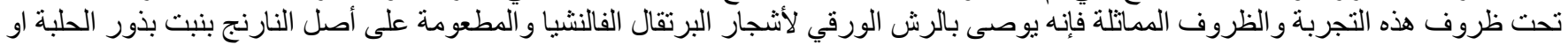

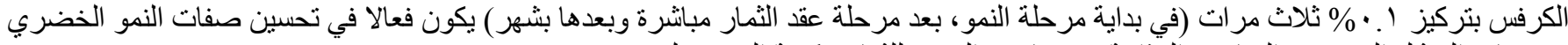

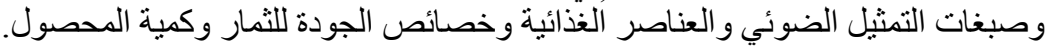

الكلمات الداله: البصل ـ الثوم _ الثعير - القمح ـ الجرجير - الكرفس ـ الحلبة_ اشجار البرتقال الفالنشيا ـ كمية المحصول - خصائص الجوده 